\title{
UPAYA PENINGKATAN PRESTASI BELAJAR MAHASISWA MELALUI INTERAKSI KELAS PADA MATA KULIAH METODOLOGI PENELITIAN
}

\author{
Hanna Sri Mudjilah \\ FBS Universitas Negeri Yogyakarta \\ E-mail: lirabarasizebua@yahoo.co.id
}

\begin{abstract}
Abstrak
Penelitian bertujuan untuk mendeskripsikan upaya peningkatan prestasi belajar mahasiswa melalui interaksi kelas pada mata kuliah metodologi penelitian pendidikan seni musik. Penelitian ini menggunakan metode penelitian tindakan kelas yang terdiri dari dua siklus. Tiap-tiap siklus terbagi dalam 4 tahap yaitu perencanaan, implementasi tindakan, observasi dan monitoring, serta analisis dan refleksi. Dari kedua siklus ini telah dilakukan dengan baik. Hasil penelitian ini adalah terjadi peningkatan nilai hasil belajar mahasiswa yang mengikuti mata kuliah metodologi penelitian pendidikan seni musik dari rata-rata kelas pada pra siklus 61.289 meningkat menjadi 66.553 pada akhir siklus 1, terjadi peningkatan prestasi sebesar 5.264 point. Hal ini dirasakan belum mencapai tujuan penelitian. Kemudian dilanjutkan pada siklus 2 dengan hasil pada akhir siklus 2 yaitu dari rata-rata akhir siklus 1 (66.553) meningkat pada akhir siklus $2(76,816)$, atau terjadi peningkatan sebesar 10.263 point. Hal ini dirasakan sudah cukup dan telah mencapai tujuan penelitian. Nilai kelulusan berada di atas $75 \%$ dari nilai kelulusan.
\end{abstract}

Kata kunci: interaksi kelas, metodologi penelitian

\section{The Efforts of Increasing Students' Learning Achievement through Class Interaction in Research Methodology Course}

\begin{abstract}
This research aims to describe the efforts of increasing students' learning achievement through class interaction in Research Methodology Course in Music Education Department. This research was conducted using action research with two cycles. Each cycle is divided into 4 stages, that is planning, implementing observing and monitoring, and analyzing and reflecting. The result shows that the students' learning achievement increased from the mean grade at pre-cycle 61.289 becomes 66.553 at the end of cycle 1 , which means that the achievement increases in 5.264 point. This result was not satisfying, and the research continued to the next cycle, with the mean grade of 66.553 at the final result of cycle 1 increasing into the mean grade of 76,816 at cycle 2 , which means that the mean grade increases 10.263 point. This is a satisfying result, with the passing grade above $75 \%$.
\end{abstract}

Keywords: class interaction, research methodology 


\section{PENDAHULUAN}

Dunia pendidikan saat ini tengah menjadi perhatian bagi banyak kalangan, mulai dari pemerintah pusat, pemerintah daerah, para guru, siswa, dan para stakeholder.Maraknya pemberitaan seputar pendidikan mengundang respon baik pro maupun kontra. Masyarakat sudah mulai pandai memilih kualitas dibanding dengan kuantitas suatu pendidikan.Kualitas seorang guru dapat dilihat dari seberapa kompetensi yang dimiliki, baik kompetensi mengajar maupun meneliti.Kompetensi meneliti saat ini bagi seorang guru sangat diperlukan terkait dengan sertifikasi guru yang menuntut adanya kompetensi di bidang penelitian.

Lembaga Perguruan Tinggi Keguruan (LPTK) yang akan menghasilkan calon-calon guru juga perlu membekali para mahasiswanya untuk lebih menguasai materi-materi setiap mata kuliah yang diberikan. Penguasaan materi atau kompetensi bagi seorang calon guru ditentukan juga oleh seberapa jauh tingkat penguasaan materi kuliah, khususnya di bidang penelitian.Salah satu mata kuliah yang memberikan kemampuan untuk meneliti adalah mata kuliah metodologi penelitian.Penguasaan materi dalam mata kuliah metodologi penelitian mempengaruhi penguasaan seorang mahasiswa dalam menyusun proposal penelitiannya, sebagai salah satu syarat untuk meraih jenjang pendidikannya. Sehingga dosen perlu memfasilitasi kualitas pembelajaran mata kuliah metodologi penelitian dengan memberikan inovasi untuk meningkatkan kualitas pembelajarannya.

Kualitas pembelajaran yang dikehendaki adalah yang mampu memberikan pengetahuan dan pengalaman para peserta didik, mulai dari sekolah dasar, menengah, maupun pada tingkat tinggi, dalam hal ini adalah perguruan tinggi. Jurusan Pendidikan Musik, FBS-UNY adalah salah satu lembaga perguruan tinggi yang termasuk dalam LPTK, yang akan menghasilkan calon-calon guru kelak.Jurusan Pendidikan Seni Musik juga menyelenggarakan mata kuliah metodologi penelitian pada semester 6, dan PPL/KKN pada semester khusus sesudah semester 6.Diharapkan setelah mengikuti mata kuliah metodologi 
penelitian, mahasiswa dapat mencari atau menemukan permasalahan di lapangan agar dapat diteliti sebagai tugas akhir untuk mencapai jenjang Strata 1.

Sebagai lembaga LPTK, saat ini harus dapat menghasilkan calon guru yang berkompeten di bidangnya, khususnya dalam bidang musik.Mata kuliah yang diselenggarakan pada jurusan pendidikan seni musik terbagi dalam dua kelompok, yaitu mata kuliah musik dan non-musik.Mata kuliah non-musik, termasuk di dalamnya adalah mata kuliah Metodologi Penelitian Pendidikan Seni Musik, sebagai salah satu mata kuliah yang mendukung penyelesaian tugas akhir mahasiswa.Berdasarkan observasi/pengamatan di jurusan pendidikan seni musik selama beberapa semester ini, pemahaman dan penguasaan mahasiswa pada mata kuliah ini dirasakan masih belum mencapai tujuan yang diharapkan. Hal ini sering dialami para mahasiswa yang sudah waktunya untuk menulis skripsi maupun mengajukan proposal penelitiannya sebagai tugas akhir masih merasa kebingungan dan tidak tahu harus berbuat apa. Proses pembelajaran yang sering terjadi masih bersifat konvensional, kurang melibatkan peran aktif mahasiswa, sehingga para mahasiswa belum siap untuk menghasilkan sebuah proposal untuk penelitiannya kelak.

Berdasarkan pengalaman mengajar beberapa tahun ini, dirasakan perlu adanya suatu inovasi baru dalam proses pembelajaran mata kuliah Metodologi Penelitian Pendidikan Seni Musik ini. Sebuah pembelajaran pada hakekatnya ditentukan oleh beberapa faktor, yakni adanya metode, materi, guru/dosen, peserta didik/mahasiswa, karyawan, serta sarana dan prasarana kegiatan pembelajaran yang saling mendukung terlaksananya pembelajaran tersebut.Untuk melakukan inovasi pembelajaran dapat dilakukan beberapa pembaruan pada masing-masing faktor tersebut. Metode ataupun cara dalam proses pembelajaran sangat bervariasi.Seorang guru/dosen berhak untuk melakukan pembaruan tersebut, sehingga dapat meningkatkan kualitas peserta didik/mahasiswa.

Permasalahan yang sering muncul di kalangan mahasiswa adalah untuk mengawali dalam penulisan proposal penelitian.Penentuan topik sering menjadikan mahasiswa salah dalam mengawali. Yang terjadi saat ini menurut pengamatan, mereka masih terpola dengan: 'saya ingin menulis apa?', atau 'saya 
ingin meneliti $X$ '. Sebagian besar dari para mahasiswa berangkat bukan dari permasalahan yang ada, sehingga seringkali ketika sudah sampai pada tahap pengumpulan data menjadi terkendala karena permasalahan yang sebenarnya tidak ada.Banyaknya permasalahan maupun kegagalan inilah yang mendorong dilakukannya penelitian ini, untuk mengantisipasi kebingungan maupun ketidaksiapan mahasiswa dalam penulisan proposal penelitiannya.

Penelitian ini berangkat dari permasalahan bahwa banyak mahasiswa yang masih kebingungan untuk mengawali menulis proposal penelitian.Untuk mengatasi hal tersebut, perlu dilakukan suatu inovasi baru dalam pembelajaran metodologi penelitian, sehingga para mahasiswa dapat lebih memahami dan menguasai permasalahan dalam menulis proposal penelitian.

Model pembelajaran interaksi kelas sebagai bagian dari metode pembelajaran sangat menentukan suatu keberhasilan dalam pembelajaran.Model pembelajaran yang menarik dan tepat untuk diterapkan dalam mata kuliah ini adalah model pembelajaraninteraksi kelas.Interaksi kelas perlu dibangundalam pelaksanaan pembelajaran dengan melibatkan para mahasiswa untuk dapat berinteraksi dengan sesama mahasiswa, mahasiswa dengan dosen, dan interaksi antar kelompok.Penerapan model pembelajaran interaksi kelas ini diharapkan dapat menjadi jalan keluar bagi penguasaan materi mata kuliah metodologi penelitian pendidikan seni musik.Motivasi dan dorongan dari dosen sangat berarti bagi mahasiswa yang malu untuk mengemukakan pendapatnya maupun untuk bertanya. Berdasarkan latar belakang permasalahan yang telah diuraikan sebelum ini, maka perlu dirumuskan permasalahan tersebut, yaitu: Apakah interaksi kelas dapat meningkatkan prestasi dan aktivitas mahasiswa pada mata kuliah Metodologi Penelitian Pendidikan Seni Musik?

\section{TINJAUAN PUSTAKA}

Interaksi sosial didasari oleh teori belajar Gestalt, yaitu belajar secara utuh.Teori Gestalt menitikberatkan pada hubungan yang harmonis antara individu dengan masyarakat (learning to life together) (Danasasmita, 2005).Sebagai salah satu model pembelajaran, interaksi sosial atau interaksi kelasdapat menjadikan 
suasana pembelajaran di kelas menjadi hidup, karena mahasiswa berperan aktif.Bjorklund dan Parente dalam Kumara dan Harsono (2005: 2) menyatakan bahwa: kualitas interaksi kelas akan mempengaruhi kualitas prestasi dan kepuasan mahasiswa dalam memperoleh pengalaman dan pengetahuan akan materi yang dipelajarinya. Lebih lanjut dikatakan bahwa:

dari hasil penelitiannya, interaksi kelas secara signifikan akan meningkatkan keterampilan professional, dengan umpan balik yang disampaikan oleh dosen secara konstruktif; di samping itu interaksi kelas menumbuhkan kesadaran baik bagi para dosen maupun mahasiswa bahwa tujuan pembelajaran akan tercapai sesuai dengan yang dikehendaki. Kumara dan Harsono (2005:3)

Aplikasi teori Gestal dalam pembelajaran mencakup: 1) pengalaman Insight/tilikan, 2) pembelajaran yang bermakna, 3) perilaku bertujuan, 4) prinsip ruang hidup (life space) (Danasasmita, 2005).

Beberapa faktor yang berperan dalam interaksi kelas adalah dosen, mahasiswa, kebijakan fakultas.Dosen sebagai fasilitator dalam kegiatan ini harus mampu memberikan umpan yang baik untuk direspon oleh mahasiswa sebagai peserta pembelajaran.Dosen dituntut mampu dan mau meluangkan waktunya untuk melakukan diskusi dan bimbingan di luar jadwal yang sudah terjadwal. Dosen merancang kegiatan perkuliahan sedemikian rupa sehingga mahasiswa dapat berinteraksi dengan sesama mahasiswa yang lain, maupun dengan dosen, bahkan interaksi antar kelompok. Mahasiswa juga dituntut untuk dapat bertanggungjawab dan mengerti arah dan minat belajarnya, dan mampu mengelola waktu untuk keseimbangan antara kegiatan akademik maupun non akademik. Hal ini tidak akan berjalan dengan baik jika tidak didukung oleh kebijakan fakultas sebagai sebuah lembaga yang mewadahi kegiatan perkuliahan.

Lebih jauh Danasasmita (2009) menyatakan bahwa model interaksi sosial ini mencakup strategi pembelajaran: 1) kerja kelompok, 2) pertemuan kelas, 3) pemecahan masalah, 4) model laboratorium, 5) bermain peran, dan 6) simulasi sosial. 


\section{METODE PENELITIAN}

Penelitian ini menggunakan pendekatan penelitian tindakan kelas.Penelitian Tindakan Kelas pertama kali dikembangkan oleh Kurt Lewis pada tahun 1946, awalnya dilakukan seorang guru untuk melakukan penelitian yang tidak mengganggu tugas rutinnya. Penelitian tindakan merupakan cara suatu kelompok atau seseorang dalam mengorganisasi sebuah kondisi dimana mereka dapat mempelajari pengalaman mereka dan membuat pengalaman mereka dapat diakses oleh orang lain. (Sukardi, 2013: 3)

\section{Setting Penelitian}

Penelitian ini akan dilakukan selama delapan (8) bulan efektif, dilakukan di Jurusan Pendidikan Seni Musik, FBS-UNY, khususnya pada mata kuliah Metodologi Penelitian kelas C. Subjek penelitian adalah seluruh mahasiswa yang mengikuti mata kuliah Metodologi Penelitian kelas C, dengan jumlah 42 mahasiswa. Kelas ini terdiri dari satu angkatan yaitu angkatan 2012.Penelitian ini dilakukan di dalam kelas yang peneliti ampu. Dengan dibantu oleh dua orang mahasiswa sebagai anggota tim penelitian.

\section{Prosedur Penelitian}

Penelitian ini terdiri dari siklus-siklus, yang tiap siklus terdapat empat tahapan, yaitu perencanaan, implementasi tindakan, observasi dan monitoring, dan refleksi.

\section{Perencanaan;}

Pada tahap ini peneliti mengidentifikasi permasalahan dan merencanakan cara untuk mengatasi bagaimana permasalahan itu dapat teratasi, peneliti membuat rencana alternatif tindakan untuk mengembangkan dan meningkatkan prestasi mahasiswa dalam membuat proposal penelitian, danmembuat rencana pelaksanaan kegiatan sesuai dengan alternatif tindakan yang telah dipilih untuk mengatasi permasalahan yang ada.

\section{Implementasi Tindakan}

Pada tahap ini dosen membagi kelas dengan beberapa kelompok kecil, beranggotakan 3-4 orang dalam setiap kelompok. Berikutnya dosen akan memberikan motivasi dan dorongan kepada para mahasiswa untuk saling 
berinteraksi dalam memecahkan permasalahan yang diberikan dosen. Para mahasiswa melakukan interaksi kelas dengan sesama dalam kelompok, dengan dosen, maupun antar kelompok, sehingga terjadi interaksi yang positif.

\section{Observasi dan monitoring;}

observasi dilakukan dengan pengamatan terhadap proses berlangsungnya pembelajaran dengan mengamati interaksi yang terjadi antar mahasiswa, mahasiswa dengan dosen, dan antar kelompok. Monitoring dilakukan oleh dosen pengampu, dibantu oleh mahasiswa sebagai anggota tim penelitian. Keikutsertaan mahasiswa dalam memonitor telah melalui pelatihan terlebih dahulu mengenai apa dan bagaimana yang harus dilakukan dalam melakukan monitoring tersebut. Monitoring dilakukan pada saat terjadi proses pembelajaran di kelas dalam siklus yang berjalan.

\section{Analisis dan Refleksi}

Pada tahap keempat ini tim peneliti melakukan refleksi atas hasil dari monitoring tersebut. Kemudian membahas apakah tindakan yang diberikan pada siklus pertama telah mencapai tujuan penelitian. Jika hasil dari refleksi menyatakan bahwa dari hasil monitoring terhadap implementasi tindakan belum mencapai tujuan penelitian, maka tim peneliti merencanakan siklus yang berikutnya.

\section{Teknik Pengumpulan Data}

Teknik pengumpulan data dalam penelitian ini melalui observasi, kuesioner, dan tes prestasi.Pengumpulan data melalui observasi dilakukan pada saat implementasi tindakan dilakukan dengan mengamati interaksi antar mahasiswa, mahasiswa dengan dosen, dan antar kelompok mahasiswa.Teknik kuesioner dilakukan dengan menyebarkan angket kepada seluruh mahasiswa terkait dengan model pembelajaran interaksi kelas.Bagaimana respon mahasiswa terhadap model pembelajaran tersebut, serta bagaimana pendapat mahasiswa terhadap kelebihan dan kekurangan dari model pembelajaran tersebut.

\section{Teknik Analisis Data}


Analisis Data dalam penelitian tindakan kelas ini menggunakan analisis deskriptif kualitatif yang didukung oleh data prestasi belajar mahasiswa sebagai data prestasi mahasiswa.Data prestasi mahasiswa dipergunakan untuk menyimpulkan apakah telah terjadi perubahan baik ke arah positif maupun negatif, setelah dilakukan tindakan atau treatment.

\section{Kriteria Keberhasilan Tindakan}

Kriteria keberhasilan dalam penelitian ini adalah jika tercapai hasil tes akhir setelah siklus terakhir menunjukkan bahwa prestasi mahasiswa mencapai tingkat kelulusan minimal $75 \%$.

\section{Validitas}

Validitas yang digunakan adalah 5 kategori validitas yang dimaksud dari Sukardi (2013: 87-89),yaitu bahwa:

a. Validitas hasil, yang peduli dengan sejauh mana tindakan dilakukan untuk memecahkan masalah dam mendorong dilakukannya penelitian tindakan atau dengan kata lain, seberapa jauh keberhasilan dapat dicapai.

b. Validitas proses, yaitu memeriksa kelaikan proses yang dikembangkan dalam berbagai fase penelitian tindakan. Misalnya, bagaimana permasalahan disusun kerangka pemikirannya dan bagaimana menyelesaikannya, sedemikian rupa sehingga peneliti didalam menghadapinya mendapat kesempatan belajar sesuatu yang baru

c. Validitas demokratis, yaitu merujuk kepada sejauhmana penelitian tindakan secara kolaboratif dengan para mitra peneliti.

d. Validitas katalitik, yakni sejauhmana peneliti berupaya mendorong partisipasi mereorientasikan, memfokuskan dan memberi semangat untuk membuka diri terhadap transformasi visi mereka dalam menghadapi kenyataan kondisi praktek mengajar mereka sehari-hari. 
e. Validitas dialog, yakni merujuk kepada dialog yang dilakukan dengan sebaya mitra peneliti dalam menyusun dan mereview hasil penelitian beserta penafsirannya.

\section{HASIL PENELITIAN DAN PEMBAHASAN}

Penelitian ini dilakukan pada semester genap tahun akademik 2014/2015 pada semester VI kelas C. Adapun pelaksanaan penelitian ini terbagi dalam 2 siklus, dimana siklus 1 dilaksanakan sebagai berikut:

\section{Perencanaan Siklus 1}

Sebelum pelaksanaan siklus 1 ini, para mahasiswa telah diambil nilai sebagai bahan untuk melihat apakah penelitian ini berhasil atau tidak, sebagai nilai Pra siklus.Para mahasiswa diberikan kesempatan untuk menuliskan terlebih dahulu proposal penelitiannya, dibuat sebagaimana adanya.

Dosen mempersiapkan pembelajaran terkait materi Pendahuluan, Masalah, dan Tujuan Penelitian, mengkondisikan ruangan sebagai tempat untuk melaksanakan penelitian ini.Apa saja yang termasuk dalam Latarbelakang penelitian dijelaskan seluruhnya pada bagian ini. Planning yang direncanakan sebagai tindakan pada siklus 1 dijelaskan kepada para mahasiswa, yaitu bagaimana menuliskan segala permasalahan yang ada. Hal yang menyangkut bab 3, diberikan metodologi penelitian yang mengarah kepada masing-masing penelitian. Ada yang memilih PTK (PTK), Research \& Development (R\&D), Penelitian Eksperimen, dan Penelitian Survey.

\section{Implementasi Tindakan}

Pada kesempatan ini dosen memberikan materi mengenai Bab 1, bagaimana menuliskan latarbelakang permasalahan, menceritakan permasalahan dan tujuan penelitian.Dosen memberikan pemahaman tentang bagaimana menemukan permasalahan, dan menceriterakan mengapa terjadinya permasalahan tersebut.Setelah semuanya diceriterakan, barulah menuliskan batasan, rumusan masalah, dan tujuan penelitian. Pada awalnya para mahasiswa kesulitan 
menuliskan semuanya itu, tetapi setelah dipandu dan diberi pemahaman, barulah mereka memahami apa itu permasalahan. Perlu diketahui bahwa permasalahan adalah sesuatu yang netral, bukan masalah yang selalu bersifat negative, akan tetapi permasalahan bisa juga bersifat positif, dan baik.

Setelah sampai pada rumusan masalah, langkah berikutnya adalah menuliskan tujuan penelitiannya.Rumusan masalah diambil dari latarbelakang permasalahan yang telah diuraikan.Selanjutnya dilanjutkan dengan Tujuan penelitian yang sesuai dengan rumusan masalah.

Hal yang terkait pada bab 3 yaitu metodologi penelitian adalah metodologi penelitian yang digunakan sesuai dengan tujuan penelitian. Ada yang meneliti menggunakan antara lain: Penelitian Tindakan Kelas (PTK), Research of Development (R \& D), Penelitian Eksperimen, dan Penelitian Survey.

\section{Observasi dan Monitoring}

Dosen memberikan monitoring kepada mahasiswa dan membantu memberikan cara yang mudah untuk menuliskan Bab 1. Pada bagian ini, dosen memberikan pemantauan dengan teliti, bagaimana cara menuliskan bagian Pendahuluan dengan benar. Bagaimana metodologi penelitian yang tepat yang akan diambil dalam penelitiannya.

\section{Analisis dan Refleksi}

Setelah melakukan monitoring, dosen berdiskusi dengan mahasiswa anggota penelitian, tentang bagaimana jalannya penelitian ini. Didapatkan hasil bahwa pada siklus 1 ini dapat berjalan dengan cukup baik tetapi masih belum mencapai tujuan penelitian, karena nilai yang diperoleh seperti berikut ini:

\begin{tabular}{|c|l|c|c|}
\hline No & Responden & Pra Siklus & Siklus 1 \\
\hline 1 & EI & 65 & 65 \\
\hline 2 & AD & 65 & 67 \\
\hline 3 & ILVT & 50 & 60 \\
\hline 4 & ARM & 70 & 78 \\
\hline 5 & TKI & 68 & 70 \\
\hline
\end{tabular}




\begin{tabular}{|c|l|c|c|}
\hline 6 & DAR & 60 & 60 \\
\hline 7 & TDA & 65 & 72 \\
\hline 8 & ZA & 65 & 73 \\
\hline 9 & AAP & 60 & 67 \\
\hline 10 & SP & 62 & 68 \\
\hline 11 & DTW & 60 & 66 \\
\hline 12 & NJL & 65 & 72 \\
\hline 13 & RFP & 60 & 60 \\
\hline 14 & LJS & 60 & 60 \\
\hline 15 & IPPP & 60 & 68 \\
\hline 16 & MSL & 56 & 60 \\
\hline 17 & FXIPW & 60 & 68 \\
\hline 18 & DABS & 60 & 65 \\
\hline 19 & FEIR & 58 & 69 \\
\hline 20 & NMP & 65 & 70 \\
\hline 21 & SA & 65 & 72 \\
\hline 22 & PDIR & 60 & 65 \\
\hline 23 & LPP & 60 & 65 \\
\hline 24 & AAA & 60 & 65 \\
\hline 25 & YSPK & 70 & 73 \\
\hline 26 & ASMN & 60 & 63 \\
\hline 27 & W & 56 & 67 \\
\hline 28 & EWN & 60 & 63 \\
\hline 29 & OP & 60 & 67 \\
\hline 30 & BPWN & 60 & 65 \\
\hline 31 & FKHA & 65 & 65 \\
\hline 32 & RH & 65 & 67 \\
\hline 33 & PMDMP & 60 & 65 \\
\hline 34 & DIA & 58 & 67 \\
\hline 35 & FC & 56 & 67 \\
\hline 36 & LAS & 60 & 67 \\
\hline 37 & SHSR & 60 & 67 \\
\hline 38 & BGB & 60 & 65 \\
\hline & Rata-rata & 61.289 & 66.553 \\
\hline & & & \\
\hline
\end{tabular}

Jika dilihat dari perhitungan ini, maka pada akhir siklus 1 sudah mengalami pengembangan yaitu dengan rata-rata $\mathrm{X} 1=61.289$ menjadi $\mathrm{X} 2=66.553$ terjadi peningkatan sebesar 5.264 point.Hal ini masih belum mencapai pada tujuan yang ingin dicapai. Kemudian langkah selanjutnya adalah dengan melanjutkan penelitian ini pada silkus 2 . 
Perencanaan Siklus 2:

Dosen kembali merencanakan siklus 2 yaitu melanjutkan pelaksanaan penelitian dari siklus1.Pada bagian metodologi penelitian diberikan beberapa metodologi yang banyak digunakan pada penelitian.Seperti PTK (Penelitian Tindakan Kelas), R \& D (Research and Development), Penelitian Eksperimen, dan Penelitian Survey.

\section{Implementasi Tindakan}

Permasalahan yang ada lebih dijelaskan lagi, dan lebih difokuskan pada permasalahan yang akan diteliti. Setelah itu permasalahan dibatasi pada apa yang hendak diteliti, dan tuliskan rumusan dan tujuannya.

Dosen kembali merencanakan pembelajaran metode penelitian pendidikan seni musik, terkait dengan ini apa yang menjadi metode penelitian yang dipilih menjadikan itu sebagai metode penelitian yang dipakai. Diawali dengan PTK (Penelitian Tindakan Kelas) merupakan metode penelitian yang banyak dikerjakan bagi guru, dan dosen.Dalam penelitian ini ingin melihat apakah terdapat pengaruh yang positif terhadap hasil belajar siswa.Penelitian ini bertujuan untuk memperbaiki nilai kelas.Biasanya para mahasiswa berkolaborasi dengan guru setempat sebagai kolaborator.Research and Development ( $R \quad \& \quad D)$ merupakan metode penelitian pengembangan, yang menuntut adanya suatu produk yang dihasilkan.Untuk penelitian ini lebih jarang diambil oleh mahasiswa karena prosesnya lebih sulit.Penelitian Eksperimen adalah penelitian yang dilakukan dengan memberikan perlakuan dan tidak diberi perlakuan terhadap subjek, yang telah dibagi dua, yaitu kelompok eksperimen dan kelompok kontrol.Penelitian Survey adalah penelitian kualitatif, yang melihat, memantau kejadian-kejadian apa yang dialami, maupun memotret hal-hal yang terkait dengan penelitian.Kedua penelitian terakhir ini lebih banyak dipakai mahasiswa karena sifatnya yang mudah dan prraktis. 


\section{Observasi dan Monitoring}

Observasi dan monitoring dilaksanakan dalam pelaksanaan penelitian ini, apakah sudah dapat berjalan dengan baik. Pemahaman pada bab 1 pendahuluan dan bab 3 metodologi penelitian dipantau dengan baik, apakah masih ada yang kebingungan. Ternyata mereka sebagian besar dari para mahasiswa sudah dapat mengikuti pemahaman tentang menuliskan permasalahan yang dihadapi serta pemilihan metodologi penelitian yang sesuai.

\section{Evaluasi dan Refleksi}

Setelah mahasiswa dapat memahami permasalahan yang akan diteliti, mereka kemudian menentukan metodologi penelitian yang sesuai. Pada siklus 2 ini, mahasiswa telah benar-benar memahami dan melakukan sesuai dengan yang seharusnya.Mereka telah tepat menuliskan latarbelakang permasalahan, batasan masalah, rumusan masalah, dan tujuan penelitian.Juga dalam metodologi penelitian, mereka telah tepat memilih metodologi yang digunakan guna melakukan penelitian.

Hasil dari penelitian ini adalah berupa angka nilai yang diperoleh dari masingmasing mahasiswa peserta dalam mata kuliah Metodologi Penelitian Pendidikan Seni Musik kelas C sebagai berikut:

\begin{tabular}{|c|l|c|c|}
\hline No & Responden & Siklus & Siklus \\
& & 65 & 78 \\
\hline 1 & EI & 67 & 79 \\
\hline 2 & AD & 60 & 70 \\
\hline 3 & ILVT & 78 & 87 \\
\hline 4 & ARM & 70 & 82 \\
\hline 5 & TKI & 60 & 76 \\
\hline 6 & DAR & 72 & 79 \\
\hline 7 & TDA & 73 & 77 \\
\hline 8 & ZA & 67 & 77 \\
\hline 9 & AAP & 68 & 79 \\
\hline 10 & SP & 60 & 78 \\
\hline 11 & DTW & 72 & 79 \\
\hline 12 & NJL & 60 & 77 \\
\hline 13 & RFP & 60 & 76 \\
\hline 14 & LJS & 68 & 78 \\
\hline 15 & IPPP & & \\
\hline
\end{tabular}




\begin{tabular}{|c|c|c|c|}
\hline 16 & MSL & 60 & 77 \\
\hline 17 & FXIPW & 68 & 77 \\
\hline 18 & DABS & 65 & 78 \\
\hline 19 & FEIR & 69 & 72 \\
\hline 20 & NMP & 70 & 80 \\
\hline 21 & SA & 72 & 72 \\
\hline 22 & PDIR & 65 & 76 \\
\hline 23 & LPP & 65 & 73 \\
\hline 24 & AAA & 65 & 78 \\
\hline 25 & YSPK & 73 & 79 \\
\hline 26 & ASMN & 63 & 73 \\
\hline 27 & $\mathrm{~W}$ & 67 & 72 \\
\hline 28 & EWN & 63 & 77 \\
\hline 29 & $\mathrm{OP}$ & 67 & 79 \\
\hline 30 & BPWN & 65 & 72 \\
\hline 31 & FKHA & 65 & 73 \\
\hline 32 & RH & 67 & 83 \\
\hline 33 & PMDMP & 65 & 78 \\
\hline 34 & DIA & 67 & 78 \\
\hline 35 & $\mathrm{FC}$ & 67 & 72 \\
\hline 36 & LAS & 67 & 78 \\
\hline 37 & SHSR & 67 & 78 \\
\hline 38 & BGB & 65 & 72 \\
\hline & & 66.553 & 76.816 \\
\hline
\end{tabular}

Jika dilihat dari nilai kedua ini, maka dapat diketahui bahwa nilai akhir siklus 2 terjadi peningkatan yaitu dari sebesar $\mathrm{X} 2=66.553$ menjadi $\mathrm{X} 3=76.816$ atau terjadi peningkatan sebesar 10.263 point.Hal ini dirasakan sudah mencapai tujuan penelitian, yaitu bahwa $75 \%$ berada di atas nilai kelulusan.

\section{KESIMPULAN}

Dari hasil penelitian ini dapat ditarik kesimpulan sebagai berikut:

1. Para mahasiswa telah dan sudah dapat memahami apa yang harus dilakukan dalam menuliskan proposal penelitiannya.

2. Para mahasiswa sudah tepat menuliskan latar belakang permasalahan yang seharusnya dituliskan 
3. Para mahasiswa telah dapat memahami metodologi yang digunakan pada penelitiannya

4. Para mahasiswa telah berhasil menuliskan proposal penelitiannya

\section{RENCANA TINDAK LANJUT}

Berdasarkan pada penelitian ini bahwa seluruh mahasiswa telah tuntas dalam menuliskan proposal penelitiannya, yaitu dengan menyerahkan proposal penelitiannya sebagai syarat akhir dari mata kuliah metodologi penelitian pendidikan seni musik.Untuk langkah selanjutnya, mahasiswa diminta untuk melanjutkan proposal penelitiannya sebagai salah satu syarat untuk dapat mengambil TAS.

Setelah melakukan ini, para mahasiswa mengajukan permohonan penulisan tugas akhir yang dikonsultasikan kepada PA untuk selanjutnya dilakukan persyaratan-persyaratan yang lain. Dari hasil ini maka para mahasiswa diminta untuk segera mengajukan proposal ke Jurusan Pendidikan Seni Musik guna melanjutkan kepada jenjang berikutnya yaitu menuliskan proposal penelitian.

\section{DAFTAR PUSTAKA}

Anderson, L.W., \& Krathwohl, D.R. 2010.Pembelajaran, Pengajaran, dan Asesmen. Yogyakarta: Pustaka Pelajar.

Aries, E.F. (2011). Asesmen dan Evaluasi. Malang: Aditya Media Publishing.

Cresswell, J.W. 1994. Research design qualitative and quantitative approach.London: Sage Publication.

Damyati, mudjiono. 2002. Belajar dan pembelajaran. Jakarta: Rineka Cipta

Danasasmita, Wawan.2009. Model Pembelajaran dan Pendekatannya. Bandung: Rizqi.http://file.upi.edu/Direktori/FPBS/JUR._PEND._BAHASA JEPA NG/195201281982031.pdf 
Dariyanto, Feri, N. 2014 Teori belajar Gestalt.

https://ferdonan.wordpress.com/teori-belajar-gestalt/. diakses tanggal 10 Maret 2015

Djaali, H., \& Muljono, P. 2008.Pengukuran dalam bidang pendidikan.Jakarta: PT. Grasindo.

Kumara, Anitya; dan Harsono. 2005. Interaksi Kelas. Yogyakarta: Universitas Gajahmada.

Muhfida. 2010. Pembelajaran Konvensional. http://muhfida.com/pembelajarankonvensional/ diakses tanggal 26 januari 2013

Mundir, H. 2013. Statistik Pendidikan. Yogyakarta: Pustaka Pelajar

Purwanto, M.N. (2012). Prinsip-prinsip dan Teknik Evaluasi Pengajaran. Bandung: PT Remaja Rosdakarya

Sari, Ni MD Liana Armita, Parmiti, dan Murda. 2013. Pengaruh Nodel Pembelajaran Interaksi Sosial terhadap Hasil Belajar IPS Siswa Kelas IV di SD Gugus 1 Kec. Tabanan.Singaraja: Universitas Pendidikan Ganesha.

Sugiyono. (2006). Metode Penelitian Kuantitatif Kualitatif dan $R \& D$. Bandung: Penerbit Alfabeta.

Sukardi, HM. 2013.Metode Penelitian Pendidikan Tindakan Kelas. Jakarta: Bumi Aksara

Walgito, Bimo. 2002. Psikologi Sosial (suatu pengantar). Yogyakarta: ANDI 